\author{
JANUSZ KiRENKO \\ Uniwersytet Marii Curie-Skłodowskiej w Lublinie \\ ORCID - 0000-0002-6525-4007
}

\title{
PODMIOTOWE KORELATY \\ UMIEJĘTNOŚCI PROSPOŁECZNYCH STUDENTÓW KIERUNKÓW NAUCZYCIELSKICH
}

\begin{abstract}
Streszczenie: Rozwiązując główny problem badawczy, zawarty w pytaniu o związki między zmiennymi, zależnej - umiejętności prospołecznych, i niezależnymi, zwanymi podmiotowymi, w wymiarach: asertywności, radzenia sobie w sytuacjach trudnych i samooceny, przebadano za pomocą: Kwestionariusza umiejętności społecznych (KUS - A.P. Goldstein), Kwestionariusza asertywności nauczyciela-wychowawcy (KAN/W - T. Zubrzycka-Maciąg, J. Kirenko), Kwestionariusza COPE (COPE - C.S. Carver, M.S. Scheier, J.K. Weintraub) i Skali samooceny (SES - M. Rosenberg) 244 studentów kierunków nauczycielskich, w tym 222 kobiety (90,98\%) i 22 mężczyzn (9,02\%). Wiek badanych mieścił się w przedziale od 21 do 46 lat, ze średnią na poziomie 25,29 lat. Byli to studenci pedagogiki, filologii angielskiej oraz pedagogiki przedszkolnej i wczesnoszkolnej z trzech uczelni regionu lubelskiego. Uzyskano specyficzną strukturę związków wybranych zmiennych, uwypuklano te, które mają znaczne oparcie w empirii. Zastosowana regresja wieloraka umożliwiła przyjęcie w miarę precyzyjnych charakterystyk otrzymanych związków, pretendujących do miana autonomicznych wniosków.
\end{abstract}

Słowa kluczowe: studenci kierunków nauczycielskich, umiejętności prospołeczne asertywność, radzenie sobie w sytuacjach trudnych, samoocena

\section{WPROWADZENIE}

Zawód nauczyciela wymaga nieustannego i coraz silniejszego emocjonalnego angażowania się osób go wykonujących. Wzrastająca liczba sytuacji trudnych, problemowych interakcji społecznych, przy malejącym poczuciu skuteczności podejmowanych działań stricte pedagogicznych, zwłaszcza możliwości doświadczania sukcesów wraz z nieodłączną presją społeczną, wymusza niekiedy na na- 
uczycielach potrzebę ukrywania własnych przekonań, a to powoduje wzrost stresu i napięcia emocjonalnego. To z kolei generuje potrzebę stosowania określonych środków zaradczych, chociażby pod postacią różnych sposobów lub strategii radzenia sobie, jako nieodzownych elementów szeroko rozumianej profesjonalizacji zawodu. Nie zapominając, że jest ona ściśle skorelowana także z permanentnym dokształcaniem się i doskonaleniem swoich umiejętności, nawet w sytuacji braku pomocy merytorycznej, czy też z realnie niskimi uposażeniami w stosunku do wykształcenia, wymaganych kompetencji i odpowiedzialności, nie mówiąc już o błędach przełożonych (zob. Kirenko, Zubrzycka-Maciąg 2011) czy wieloletnich zaniedbaniach w polityce oświatowej kraju.

Szczególnie istotną rolę odgrywają kompetencje zawodowe nauczycieli rozumiane jako konieczny poziom umiejętności metodycznych i merytorycznych oraz wiedzy, a także konieczność prezentowania właściwych postaw w stosunku do uczniów oraz realizacji zadań szkolnych według cech sprawnego działania i reguł współpracy (Kacprzak 2006). Spośród ich licznych klasyfikacji, m.in. specjalistycznych, dydaktycznych i psychologicznych (por. Kacprzak 2006), czy też: bazowych, koniecznych i pożądanych (por. Dylak 1995), nieodzowne są tutaj kompetencje konieczne, zwłaszcza: interpretacyjne, autokreacyjne i realizacyjne, rozpatrywane $\mathrm{w}$ aspektach wartości pedagogicznych, wiedzy przedmiotowej oraz wiedzy i umiejętności pedagogicznych, których podstawą jest samowiedza, w tym świadomość relacji z innymi ludźmi, pozwalające w sposób bezpośredni na realizację zadań edukacyjnych w placówce (Dylak 1995).

Lista przymiotów, którymi powinien się charakteryzować współczesny nauczyciel, jest bardzo długa, począwszy od: inteligencji, błyskotliwości, kreatywności w myśleniu, pomysłowości, odwagi w działaniu, aktywności, sumienności, pracowitości, skromności, odpowiedzialności i systematyczności; poprzez: bycie sprawiedliwym, wymagającym, pomocnym, empatycznym, wyrozumiałym, tolerancyjnym, cierpliwym, życzliwym i otwartym; a skończywszy na: dobrym zorganizowaniu, autentyczności, otwartości na zmiany i powołaniu do zawodu (zob. Karolczak-Biernacka 1996).

Niezwykle ważne jest zatem posiadanie przez przyszłych nauczycieli nieodzownych umiejętności prospołecznych, potocznie określanych umiejętnościami interpersonalnymi, psychospołecznymi, komunikacyjnymi, interakcyjnymi czy też społecznymi, w skład których wchodzą np. asertywność, komunikacja niewerbalna i werbalna, empatia, współpraca, rozwiązywanie konfliktów oraz autoprezentacja i altruizm. Są to zdolności psychiczne i kompetencje praktyczne wykorzystywane w sytuacjach społecznych, przynoszące korzyść członkom interakcji społecznych, w celu nawiązywania kontaktów z innymi ludźmi i współżyć w społeczeństwie. Pozytywnie wpływają one na samopoczucie człowieka i jego samoocenę oraz 
funkcjonowanie w różnych sytuacjach społecznych, by osiągał sukcesy w życiu prywatnym i zawodowym (zob. Kirenko 2019).

Obserwowana przypadkowość wyboru kierunku studiów i często niedostatek oceny predyspozycji pedagogicznych na etapie rekrutacji sprawia, że wielu studentów przygotowujących się do zawodu nauczyciela nie będzie w stanie sprostać tej profesji. Podejmując bowiem studia pedagogiczne, nie brali oni pod uwagę swoich relacji i umiejętności społecznych jako skutecznego społecznego działania, osadzonego w kontekście wielu zmiennych tkwiących w aktywności jednostki i jej otoczeniu, takich chociażby, jak: asertywność, radzenie sobie ze stresem i samoocena, by sprostać wymaganiom stawianym już w pracy zawodowej (zob. Kirenko 2019).

Istnieją trzy podstawowe ujęcia teoretyczne istoty asertywności: behawioralne, ujmujące ją jako zespół wyuczonych umiejętności, sprawności lub ukształtowanych nawyków reagowania w różnych sytuacjach społecznych, służących ekspresji siebie oraz wyrażaniu własnych praw w sposób akceptowany społecznie; kognitywne, uwzględniające rolę zmiennych poznawczych w generowaniu gotowości do przejawiania asertywności, gdzie obok umiejętności pełnego wyrażania siebie asertywność obejmuje specyficzny sposób myślenia ściśle związany z poczuciem własnej godności i szacunkiem do samego siebie; ostatnie, behawioralno-poznawczo-fenomenologiczne, należy do najpełniejszych ujęć tego zjawiska, ponieważ utożsamiane jest z dyspozycją osobowościową, opisywaną łącznie w trzech współzależnych wymiarach funkcjonowania człowieka: poznawczym, przeżyciowym i behawioralnym, odnoszącym się do zachowań i warunkujących je umiejętności. Według Ryszarda Poprawy (2001, s. 114) jest „osobowościową dyspozycję do specyficznego sposobu autoekspresji własnych przekonań i uczuć oraz radzenia sobie z wymaganiami relacji życiowych dotyczących głównie kontaktów interpersonalnych”. Stąd łączy w sobie trzy współdziałające komponenty: adekwatną wiedzę, zespół umiejętności i gotowość poznawczo-afektywną.

Natomiast pojęcie radzenie sobie to zdaniem Richarda S. Lazarusa i Susan Folkman (1984, s. 141) „,stale zmieniający się wysiłek poznawczy i behawioralny, skierowany na wymagania zewnętrzne i/lub wewnętrzne, które oceniane są przez jednostkę jako obciążające i przekraczające jej możliwości”. Wszelkie zatem działania w sytuacji stresowej zmierzają do usunięcia przeszkody lub wyeliminowania przyczyny trudności oraz poprawy samopoczucia i nastroju, a także uwolnienia się od negatywnych emocji. Mogą zatem pełnić funkcję zadaniową, skoncentrowaną na problemie, oraz regulacyjną, skoncentrowaną na emocjach (Lazarus, Folkman 1984). Istnieje duża różnorodność indywidualnych wzorców radzenia sobie, a o tym, która $\mathrm{z}$ funkcji procesu radzenia sobie będzie podstawowa oraz jaka będzie dynamika przemian jednej w drugą, decydują przede wszystkim: indywidualne znaczenie, jakie nadawane jest transakcji stresowej przez procesy 
oceny poznawczej oraz możliwości zaradcze danej osoby. Ponieważ owe funkcje nie są rozłączne i niezależne, przeplatają się i wzajemnie na siebie oddziałują. Kongruencja funkcjonalna strategii oraz umiejętność prawidłowego ich doboru zależy od posiadanego przez człowieka zestawu strategii zaradczych i od ogólnej orientacji człowieka w swoim otoczeniu i jego wymagań (Ratajczak 1996), czyli warunkowane jest jednak nie tylko sposobem spostrzegania wymagań, jakie niesie dana sytuacja, ale także charakterystycznym dla danej osoby stylem radzenia sobie w sytuacjach trudnych (por. Kirenko 2019).

Samoocena zaś to poczucie własnej wartości, reakcja na samego siebie, inaczej postawa wobec samego siebie, swoich cech, możliwości, zdolności i wad, stanowiąca emocjonalny komponent obrazu własnej osoby, czyli zespół różnorodnych sądów i opinii, które jednostka odnosi do siebie, a dotyczą one fizycznych, psychicznych i społecznych właściwości danego człowieka (zob. Kirenko 1991). To również rodzaj globalnej oceny samego siebie, warunkowanej czynnikami wewnętrznymi i zewnętrznymi. Jest strukturą dynamiczną. Nie jest ona homogeniczna, nie wiąże się więc z jednym wymiarem życia człowieka. Może być cząstkowa i globalna, wielokrotnie ulegać odmianie i różnić się od siebie w związku z poziomem czy wartością swoich opinii. Dlatego też w samoocenie globalnej wyróżnić można postawy samoakceptacji oraz samoodtrącenia, gdy wiążą się one $\mathrm{z}$ wysokim pozytywnym lub niskim negatywnym nastawieniem do siebie. Co $\mathrm{w}$ drugim przypadku uniemożliwia człowiekowi poznanie siebie, nie pozwala się realizować (zob. Kirenko, Zubrzycka-Maciąg 2011; Kirenko 2019).

\section{PROBLEM, NARZĘDZIA I BADANA GRUPA OSÓB}

W literaturze przedmiotu są dostępne wyniki badań z zakresu kompetencji społecznych różnych grup zawodowych, w tym szczególnie szeroko rozumianych umiejętności prospołecznych nauczycieli i wychowawców. Coraz liczniejsze są również dane odnoszące się do psychospołecznych czynników je warunkujących, czyli do istnienia związków między różnymi konfiguracjami zmiennych zależnych i niezależnych, nierzadko moderujących, już nie tylko nauczycieli, ale i studentów kierunków nauczycielskich (por. Kirenko 2019). Główny problem badawczy stanowią związki między tak przyjętymi zmiennymi, zależnej - umiejętności prospołecznych, i niezależnymi, zwanymi podmiotowymi, w wymiarach: asertywności, radzenia sobie w sytuacjach trudnych i samooceny. Celem tak zaplanowanych badań jest ocena tych związków.

Dane empiryczne zebrano za pomocą metody sondażu diagnostycznego, w skład którego wchodziły następujące narzędzia badawcze: Kwestionariusz umiejętności społecznych (KUS - A.P. Goldstein), Kwestionariusz asertywności nauczyciela-wycho- 
wawcy (KAN/W - T. Zubrzycka-Maciąg, J. Kirenko), Kwestionariusz COPE (COPE C.S. Carver, M.S. Scheier, J.K. Weintraub) i Skala samooceny (SES - M. Rosenberg). KUS to narzędzie umożliwiające dokonanie oceny poziomu umiejętności prospołecznych rozumianych jako nabyte umiejętności warunkujące efektywność funkcjonowania człowieka w różnych sytuacjach społecznych, dla personelu i członków grup społecznych. Dostarcza informacji z zakresu trzech wskaźników szczegółowych, określających poziom kompetencji ujawnianych w sytuacjach ekspozycji społecznej, sytuacjach wymagających asertywności oraz sytuacjach bliskiego kontaktu interpersonalnego. Składa się z 50 twierdzeń diagnostycznych pogrupowanych w sześć grup umiejętności: wstępne umiejętności społeczne (S1), nauka zaawansowania podstawowych umiejętności społecznych (S2), umiejętności kontrolowania emocji (S3), alternatywne umiejętności wobec agresji (S4), umiejętności radzenia sobie ze stresem (S5) oraz umiejętności planowania (S6). Zadaniem osoby badanej jest wskazanie na pięciostopniowej skali, w jakim stopniu zgadza się z każdym stwierdzeniem (Goldstein $i$ in. 2008). KAN/W natomiast zawiera cztery obszary przejawianej gotowości do asertywności w kontaktach: $\mathrm{z}$ uczniami/wychowankami, z rodzicami uczniów/ wychowanków, z innymi nauczycielami i wychowawcami oraz z przełożonymi. W każdym $\mathrm{z}$ nich znajduje się siedem komponentów asertywności: obrona swoich praw (OSP), przyjmowanie ocen pozytywnych i negatywnych (POPN), wyrażanie ocen pozytywnych i negatywnych (WOPN), wyrażanie próśb (WP), wyrażanie uczuć (WU), wyrażanie opinii (WO) i szanowanie cudzych granic (SCG). W sumie są to 72 twierdzenia wyskalowane na pięciostopniowej podziałce. Wyniki w zakresie poszczególnych komponentów, obszarów i wyniku całościowego (globalnego) są sumowane (zob. Zubrzycka-Maciąg, Kirenko 2015). Tymczasem Kwestionariusz COPE pozwala ustalić możliwości radzenia sobie w sytuacjach trudnych, ujętych w aspekcie ośmiu stylów i ośmiu strategii, czyli dyspozycji do radzenia i sytuacyjności radzenia, zagregowanych w następujących skalach: koncentracja na problemie (KP), zaprzeczenie (Z), koncentracja na emocjach i ich wyładowaniu (KEW), poszukiwanie emocjonalnego wsparcia (PEW), akceptacja (A), zwracanie się ku religii (ZR), poczucie humoru $(\mathrm{PH})$, używanie alkoholu lub innych środków odurzających (UASO). Każdy item oceniany jest na czterostopniowej skali (zob. Wrześniewski 1996; por. Byra 2012). W odniesieniu zaś do ostatniej zmiennej posłużono się Skalą SES, narzędziem przeznaczonym do oceny poziomu ogólnej samooceny, ujawnianego w samoopisie, czyli względnie stałej dyspozycji rozumianej jako świadoma postawa (pozytywna lub negatywna) wobec Ja, a nie chwilowy stan. Składa się ona z 10 twierdzeń diagnostycznych. Osoba badana wskazuje na czterostopniowej skali, w jakim stopniu zgadza się z każdym z nich (zob. Dzwonkowska i in. 2008).

Badaniu poddano 244 studentów kierunków nauczycielskich, w tym 222 kobiety (90,98\%) i 22 mężczyzn (9,02\%), w wieku od 21 do 46 lat, ze średnią arytmetyczną 
25,29 lat. Byli to studenci pedagogiki (88 osób - 36,07\%), filologii angielskiej (81 osób - 33,20\%) oraz pedagogiki przedszkolnej i wczesnoszkolnej (75 osób - 30,74\%) z trzech uczelni: Wyższej Szkoły Ekonomii i Innowacji w Lublinie (137 osób 56,15\%), Uniwersytetu Marii Curie-Skłodowskiej w Lublinie (81 osób - 33,20\%) i Państwowej Wyższej Szkoły Zawodowej w Chełmie (26 osób - 10,66\%). Najliczniejsi, bo 169 osób $(69,26 \%)$, to studenci pierwszego stopnia, pozostałe 75 osób (30,74\%) drugiego. Przeważali studenci studiów niestacjonarnych (146 osób 59,84\%) nad stacjonarnymi (98 osób - 40,16\%). W większości przypadków były to osoby stanu zamężnego (149 osób - 61,07,00\%), przy 95 osobach $(38,93 \%)$ stanu wolnego, częściej mieszkające na wsi (124 osoby - 50,82\%) i w miastach od 20 do 100 tys. mieszkańców (65 osób - 26,64\%), spośród których 179 osób $(73,33 \%)$ chce podjąć pracę w szkole lub innej placówce oświatowej po ukończeniu studiów, w tym 64 osoby $(26,23 \%)$ są zdeterminowane w tym postanowieniu (por. Kirenko 2019).

\section{WYNIKI ANALIZ}

Ustalenie powiązań między sześcioma komponentami umiejętności prospołecznych a poszczególnymi zmiennymi warunkującymi psychospołeczne funkcjonowanie studentów kierunków nauczycielskich w różnych sytuacjach, zwanymi tutaj podmiotowymi, czyli: gotowości do asertywności, preferowaniu strategii radzenia sobie w sytuacjach trudnych i samooceny, możliwe było dzięki zastosowaniu analizy regresji wielokrotnej, co prezentują dane zawarte w zestawieniu tabelarycznym (tab. 1).

Tabela 1. Wyniki analizy regresji wielokrotnej: wskaźniki zmiennej zależnej umiejętności prospołecznych i zmiennych niezależnych badanych studentów

\begin{tabular}{|c|c|c|c|c|c|}
\hline \multicolumn{6}{|c|}{ Wstępne umiejętności społeczne } \\
\hline \multirow{2}{*}{\multicolumn{2}{|c|}{$\begin{array}{c}\text { Wskaźniki } \\
\text { zmiennych niezależnych } \\
\beta\end{array}$}} & \multicolumn{4}{|c|}{$R=0,66 ; R_{2}=0,43 ; F(8,23)=22,93$} \\
\hline & & $B$ & $t^{o}$ & $p$ & \\
\hline \multirow{4}{*}{ Asertywność } & POPN & $-0,29$ & $-0,18$ & $-3,67$ & $0,000^{*}$ \\
\hline & WU & $-0,26$ & $-0,24$ & $-3,13$ & $0,002^{*}$ \\
\hline & WO & $-0,21$ & $-0,16$ & $-2,54$ & $0,012^{*}$ \\
\hline & SCG & 0,32 & 0,18 & 4,40 & $0,000^{*}$ \\
\hline \multirow{3}{*}{ COPE } & $\mathrm{KP}$ & 0,19 & 0,14 & 3,53 & $0,001^{*}$ \\
\hline & UASO & $-0,16$ & $-0,28$ & $-3,08$ & $0,002^{*}$ \\
\hline & PEW & $-0,06$ & $-0,08$ & $-1,14$ & 0,257 \\
\hline Samoocena & SUMA & 0,14 & 0,13 & 2,61 & $0,010^{*}$ \\
\hline
\end{tabular}




\begin{tabular}{|c|c|c|c|c|c|}
\hline \multicolumn{6}{|c|}{ Nauka zaawansowania podstawowych umiejętności społecznych } \\
\hline \multirow{2}{*}{\multicolumn{2}{|c|}{$\begin{array}{c}\text { Wskaźniki } \\
\text { zmiennych niezależnych } \\
\beta\end{array}$}} & \multicolumn{4}{|c|}{$R=0,57 ; R_{2}=0,33 ; F(12,23)=9,44$} \\
\hline & & B & $t^{o}$ & $p$ & \\
\hline \multirow{5}{*}{ Asertywność } & WOPN & 0,20 & 0,13 & 1,80 & $0,074 \sim$ \\
\hline & WU & $-0,30$ & $-0,19$ & $-2,47$ & $0,014^{*}$ \\
\hline & WO & 0,42 & 0,21 & 3,72 & $0,000^{*}$ \\
\hline & SCG & 0,30 & 0,12 & 2,78 & $0,006^{*}$ \\
\hline & GLOBAL & $-0,83$ & $-0,07$ & $-3,42$ & $0,001^{*}$ \\
\hline \multirow{4}{*}{ COPE } & ZR & 0,13 & 0,10 & 1,91 & $0,058 \sim$ \\
\hline & $\mathrm{PH}$ & $-0,12$ & $-0,12$ & $-1,75$ & $0,082 \sim$ \\
\hline & KEW & $-0,36$ & $-0,42$ & $-4,67$ & $0,000^{*}$ \\
\hline & PEW & 0,25 & 0,23 & 3,08 & $0,002^{*}$ \\
\hline \multicolumn{6}{|c|}{ Umiejętności kontrolowania emocji } \\
\hline \multirow{2}{*}{\multicolumn{2}{|c|}{$\begin{array}{c}\text { Wskaźniki } \\
\text { zmiennych niezależnych } \\
\beta\end{array}$}} & \multicolumn{4}{|c|}{$R=0,59 ; R_{2}=0,35 ; F(10,23)=12,71$} \\
\hline & & $\boldsymbol{B}$ & $t^{o}$ & $p$ & \\
\hline \multirow{4}{*}{ Asertywność } & WU & $-0,31$ & $-0,21$ & $-2,63$ & $0,009^{*}$ \\
\hline & WO & 0,16 & 0,09 & 1,52 & 0,130 \\
\hline & SCG & 0,25 & 0,11 & 2,58 & $0,011^{*}$ \\
\hline & GLOBAL & $-0,44$ & $-0,04$ & $-2,44$ & $0,015^{*}$ \\
\hline \multirow{4}{*}{ COPE } & $\mathrm{KP}$ & 0,16 & 0,09 & 2,40 & $0,017^{\star}$ \\
\hline & A & $-0,15$ & $-0,19$ & $-2,21$ & $0,028^{*}$ \\
\hline & $\mathrm{Z}$ & $-0,29$ & $-0,41$ & $-4,99$ & $0,000^{*}$ \\
\hline & PEW & 0,12 & 0,12 & 1,93 & $0,054 \sim$ \\
\hline Samoocena & SUMA & 0,18 & 0,13 & 3,14 & $0,002^{*}$ \\
\hline \multicolumn{6}{|c|}{ Alternatywne umiejętności wobec agresji } \\
\hline \multirow{2}{*}{\multicolumn{2}{|c|}{$\begin{array}{c}\text { Wskaźniki } \\
\text { zmiennych niezależnych } \\
\beta\end{array}$}} & \multicolumn{4}{|c|}{$R=0,51 ; R_{2}=0,26 ; F(10,23)=8,26$} \\
\hline & & $B$ & $t^{o}$ & $p$ & \\
\hline \multirow{4}{*}{ Asertywność } & POPN & $-0,26$ & $-0,15$ & $-2,17$ & $0,031^{*}$ \\
\hline & WOPN & 0,22 & 0,20 & 2,19 & $0,029^{*}$ \\
\hline & WP & 0,11 & 0,10 & 1,13 & 0,260 \\
\hline & WU & $-0,24$ & $-0,21$ & $-2,04$ & $0,042^{*}$ \\
\hline \multirow{2}{*}{ COPE } & $\mathrm{PH}$ & $-0,12$ & $-0,18$ & $-2,02$ & $0,045^{*}$ \\
\hline & KEW & $-0,11$ & $-0,18$ & $-1,68$ & $0,094 \sim$ \\
\hline Samoocena & SUMA & 0,10 & 0,09 & 1,66 & $0,098 \sim$ \\
\hline
\end{tabular}




\begin{tabular}{|c|c|c|c|c|c|}
\hline \multicolumn{6}{|c|}{ Umiejętności radzenia sobie ze stresem } \\
\hline \multirow{2}{*}{\multicolumn{2}{|c|}{$\begin{array}{c}\text { Wskaźniki } \\
\text { zmiennych niezależnych } \\
\beta\end{array}$}} & \multicolumn{4}{|c|}{$R=0,61 ; R_{2}=0,37 ; F(11,23)=12,53$} \\
\hline & & B & $t^{o}$ & $p$ & \\
\hline \multirow{6}{*}{ Asertywność } & OSP & 0,26 & 0,16 & 1,64 & 0,102 \\
\hline & WOPN & 0,42 & 0,53 & 3,42 & $0,001^{*}$ \\
\hline & WP & 0,27 & 0,33 & 2,27 & $0,024^{*}$ \\
\hline & WO & 0,41 & 0,41 & 3,22 & $0,001^{*}$ \\
\hline & SCG & 0,56 & 0,42 & 4,32 & $0,000^{*}$ \\
\hline & GLOBAL & $-2,09$ & $-0,32$ & $-4,90$ & $0,000^{*}$ \\
\hline \multirow{4}{*}{ COPE } & $\mathrm{ZR}$ & 0,17 & 0,24 & 2,76 & $0,006^{*}$ \\
\hline & KP & 0,18 & 0,17 & 2,93 & $0,004^{*}$ \\
\hline & $\mathrm{PH}$ & $-0,07$ & $-0,14$ & $-1,20$ & 0,231 \\
\hline & $\mathrm{Z}$ & $-0,12$ & $-0,30$ & $-2,06$ & $0,040^{*}$ \\
\hline \multicolumn{6}{|c|}{ Umiejętności planowania } \\
\hline \multirow{2}{*}{\multicolumn{2}{|c|}{$\begin{array}{c}\text { Wskaźniki } \\
\text { zmiennych niezależnych } \\
\beta\end{array}$}} & \multicolumn{4}{|c|}{$R=0,61 ; R_{2}=0,38 ; F(9,23)=15,54$} \\
\hline & & $B$ & $t^{o}$ & $p$ & \\
\hline \multirow{4}{*}{ Asertywność } & OSP & 0,12 & 0,05 & 1,17 & 0,242 \\
\hline & POPN & $-0,18$ & $-0,11$ & $-2,02$ & $0,045^{*}$ \\
\hline & WU & $-0,26$ & $-0,24$ & $-2,83$ & $0,005^{\star}$ \\
\hline & WO & $-0,16$ & $-0,12$ & $-1,67$ & $0,096 \sim$ \\
\hline \multirow{3}{*}{ COPE } & $\mathrm{KP}$ & 0,33 & 0,25 & 5,63 & $0,000^{*}$ \\
\hline & UASO & $-0,14$ & $-0,25$ & $-2,61$ & $0,010^{*}$ \\
\hline & $\mathrm{Z}$ & $-0,21$ & $-0,40$ & $-3,94$ & $0,000^{*}$ \\
\hline Samoocena & SUMA & 0,10 & 0,09 & 1,71 & $0,088 \sim$ \\
\hline
\end{tabular}

${ }^{*} p<0,05 ; \sim-p$ zbliżone do istotności

Wśród zmiennych niezależnych składających się na model współzależnościowy ze zmienną zależną Wstępnych umiejętności społecznych w badanej grupie studentów, wyłącznie na poziomie istotności statystycznej, znalazły się cztery komponenty asertywności, dwa wskaźniki strategii radzenia sobie w sytuacjach trudnych i globalna samoocena. Stworzony model wyjaśnia $43 \%$ zmienności zmiennej zależnej. W nieco większej liczbie przypadków charakter tych zależności jest odwrotnie proporcjonalny. Stąd realizacja umiejętności: negocjowania z innymi, kontrolowania swoich uczuć i zachowań, bronienia, reagowania na zaczepki, trzymania się z boku w sytuacjach, które mogą spowodować kłopoty, mówienia innym, gdy są odpowiedzialni za problemy, czy przyznawania się, gdy zrobi się komuś coś złego, w największym stopniu warunkowane jest postawą szanowania cudzych granic, czyli zachowaniami wskazującymi na liczenie się z potrzebami innych ludzi, w tym: uważne słuchanie ich wypowiedzi pomimo towarzyszących 
emocji, respektowanie ich próśb, utrzymywanie w tajemnicy ich spraw oraz okazywanie im szacunku nawet, gdy trudno jest akceptować ich zachowania (zob. Zubrzycka-Maciąg 2011). Wyższym również stopniem świadomej, subiektywnej postawa wobec siebie, wobec innych, emocji związanych z własną osobą, powiązanej z poznawczymi sądami o sobie oraz strategią układania planu działania przy rozwiązywaniu problemu, robienia tego wszystkiego, by go rozwikłać, by nie rozpraszały i nie przeszkadzały w tym inne myśli i działania, odkładania ich na później, po to, by krok po kroku robić to, co jest do zrobienia, uczyć się tego, doświadczać. Nie tworzą natomiast relacji zależnościowych z umiejętnościami przyjmowania pochwał i krytyki w sytuacjach, w których spotyka się zarówno ze słuszną, jak i z niesłuszną oceną pozytywną lub negatywną ze strony innych ludzi oraz otwartego wyrażania uczuć w sytuacji odczuwania zadowolenia, dumy czy radości i takiego samego, czyli szczerego, wyrażania uczuć w sytuacji odczuwania niezadowolenia, irytacji i złości, a także otwartego i szczerego mówienie o podzielaniu cudzych opinii czy otwartego przyznawania się do swoich upodobań, pomimo braku zewnętrznej aprobaty dla nich, a ponadto ze strategią spożywania alkoholu lub przyjmowania innych środków odurzających.

Natomiast w modelu zmiennej zależnej Nauki zaawansowania podstawowych umiejętności społecznych, wyjaśniającym 33\% zmienności, znalazło się pięć komponentów asertywności i cztery strategie radzenia sobie w sytuacjach trudnych, na poziomie istotności statystycznej i zbliżonym do niego, z nieznaczną przewagą zależności dodatnich. Należy zatem sądzić, że wzrostowi wartości umiejętności: słuchania, rozpoczynania rozmowy, prowadzenia jej, pozwalania innym na wypowiedzenie się, szczerego komplementowania, rozpoznawania sytuacji odrzucenia, czy stawania w obronie innych, gdy zostali źle potraktowani, towarzyszy wprost proporcjonalny wzrost nastawienia na szanowanie cudzych granic, czyli zachowań wskazujących na liczenie się z potrzebami innych ludzi, w tym: uważne słuchanie ich wypowiedzi pomimo towarzyszących emocji, respektowanie ich próśb, utrzymywanie w tajemnicy ich spraw oraz okazywanie im szacunku, nawet gdy trudno akceptować ich zachowania. Dyspozycje te warunkowane są również pełnym wyrażaniem siebie $\mathrm{w}$ kontakcie $\mathrm{z}$ innymi ludźmi, $\mathrm{z}$ ujawnianiem ocen pozytywnych i negatywnych, otwartym i szczerym mówieniem o podzielaniu cudzych opinii czy przyznawaniem się do swoich upodobań, pomimo braku zewnętrznej aprobaty dla nich, a ponadto strategiami poszukiwania uczuciowego oparcia, współczucia i zrozumienia u przyjaciół lub rodziny oraz ze zwracaniem się ku religii, znalezieniem w niej ukojenia, zawierzeniem Bogu. W modelu tym istotną rolę odgrywają jeszcze wskaźniki o charakterze zależności odwrotnie proporcjonalnej, czyli braku u badanych studentów możliwości otwartego wyrażania uczuć w sytuacji odczuwania zadowolenia, dumy czy radości i takiego samego, 
czyli szczerego wyrażania uczuć w sytuacji odczuwania niezadowolenia, irytacji i złości, a także dawania upustu emocjom, manifestowaniem złej sytuacji czy też strategii dworowania sobie, a niekiedy strojenia żartów.

Zmienne niezależne zaś w wyjaśnianiu zmiennej zależnej Umiejętności kontrolowania emocji, które weszły w skład modelu regresyjnego na poziomie ufności i zbliżonym do niego, są również liczne, chociaż poziom ich zmienności wynosi 35\%. Te cząstkowe wskaźniki to cztery strategie radzenia sobie w sytuacjach trudnych, trzy komponenty asertywności i globalna samoocena, w takich samych proporcjach zależności wprost i odwrotnie proporcjonalnych. A zatem nasileniu umiejętności: zadawania pytań, okazywania wdzięczność, zaznajamia się z innymi z własnej inicjatywy, przedstawiania innych osób, nagradzania siebie, proszenia o pozwolenie czy udzielania odpowiedzi na namawianie, towarzyszy postawa szanowania cudzych granic, zachowań wskazujących na liczenie się z potrzebami innych ludzi, w tym: uważne słuchanie ich wypowiedzi pomimo towarzyszących emocji, respektowanie ich próśb, utrzymywanie w tajemnicy ich spraw oraz okazywanie im szacunku, nawet gdy trudno jest akceptować ich zachowania, a także stopień świadomej, subiektywnej postawa wobec siebie, wobec innych, emocji związanych z własną osobą, powiązanej z poznawczymi sądami o sobie. Powiązane są również ze strategiami układania planu działania przy rozwiązywaniu problemu, robienia tego wszystkiego, by go rozwikłać, by nie rozpraszały i nie przeszkadzały w tym inne myśli i działania, odkładania ich na później, po to, by krok po kroku robić to co jest do zrobienia, uczyć się tego doświadczać, ale i dawania upustu emocjom, manifestowaniem złej sytuacji. Gdy tymczasem w opozycji do analizowanych tutaj umiejętności społecznych jest postawa otwartego wyrażania uczuć w sytuacji odczuwania zadowolenia, dumy czy radości i takiego samego, czyli szczerego, wyrażania uczuć w sytuacji odczuwania niezadowolenia, irytacji i złości oraz strategie mówienia sobie, że „to nie dzieje się naprawdę”, nieprzyjmowania do wiadomości, że to się stało, udawanie i zachowywanie się tak, jakby się nie stało, a ponadto przyzwyczajania się do myśli, że to co się stało, już się „nie odstanie”, poszukiwania czegoś dobrego w tym, co się wydarzyło, uczenia się, jak z tym żyć, ale także szukania uczuciowego oparcia.

Natomiast wśród zmiennych niezależnych, na poziomie istotności statystycznej i zbliżonym do niego, w modelu zmiennej zależnej Alternatywnych umiejętności wobec agresji znalazły się trzy komponenty asertywności, dwie strategie radzenia sobie w sytuacjach trudnych i globalna samoocena. Niniejszy model wyjaśnia jedynie $26 \%$ zmienności zmiennej. Przy czym tylko w dwóch przypadkach charakter owych zależności jest wprost proporcjonalny. Analizowane zatem umiejętności: mówienia komplementów, proszenia o pomoc, przyłączania się, udzielania wskazówek, wykonywania poleceń, dzielenia się, reagowania na niepowodzenie, 
radzenia sobie ze sprzecznymi komunikatami czy oskarżeniami, w największym stopniu warunkowane są wysokim poziomem pełnego wyrażania siebie $\mathrm{w}$ kontakcie z innymi ludźmi, ujawniania ocen pozytywnych i negatywnych, otwartego i szczerego mówienia o podzielaniu cudzych opinii czy przyznawania się do swoich upodobań pomimo braku zewnętrznej aprobaty dla nich, a ponadto stopniem świadomej, subiektywnej postawy wobec siebie, wobec innych, emocji związanych z własną osobą, powiązanej z poznawczymi sądami o sobie. W opozycji do tej charakterystyki znajduje się brak umiejętności przyjmowania pochwał i krytyki w sytuacjach, w których spotyka się zarówno ze słuszną, jak i z niesłuszną oceną ze strony innych ludzi oraz otwartego wyrażania uczuć w sytuacji odczuwania zadowolenia, dumy czy radości i takiego samego, czyli szczerego wyrażania uczuć w sytuacji odczuwania niezadowolenia, irytacji i złości, a ponadto z poziomem zdenerwowania badanych studentów, którzy dają upust emocjom, manifestując to, że jest im źle, ale również z dworowaniem sobie, a niekiedy strojeniem żartów.

Uzyskane wyniki regresji wielokrotnej w zakresie współzależności zmiennej zależnej Umiejętności radzenia sobie ze stresem wskazują, że w badanej grupie współczynnik determinacji tej dyspozycji ze zmiennymi niezależnymi wynosi 37\%. W modelu funkcji regresji stwierdzono osiem cząstkowych wskaźników na poziomie istotnym statystycznie, pięć wymiarów asertywności i trzy strategie radzenia sobie w sytuacjach trudnych, w tym dwa o charakterze odwrotnie proporcjonalnym. Osoby badane zatem analizowane tu umiejętności: przepraszania i przekonywania innych, rozpoznawania i wyrażania swoich uczuć, rozumienia czyichś uczuć, radzenie sobie z czyimś gniewem, wyrażania sympatii (miłości), pomagania innym, przezwyciężania zakłopotania (wstydu), przygotowywania się do trudnej rozmowy, radzenia sobie z presją grupy czy decydowania o zrobieniu czegoś, łączą głównie z pełnym wyrażaniem siebie w kontakcie z innymi ludźmi, z ujawnianiem ocen pozytywnych i negatywnych, otwartym i szczerym mówieniem o podzielaniu cudzych opinii czy przyznawaniem się do swoich upodobań pomimo braku zewnętrznej aprobaty dla nich oraz komponentami wyrażania próśb, z upraszaniem wykonania jakiejś czynności czy też wypożyczenia, udostępnienia materiałów rzeczowych, otwartego przyznawania się do swoich upodobań pomimo braku zewnętrznej aprobaty dla nich, a ponadto z postawą szanowania cudzych granic, czyli zachowaniami wskazującymi na liczenie się z potrzebami innych ludzi, w tym: uważne słuchanie ich wypowiedzi pomimo towarzyszących emocji, respektowanie ich próśb, utrzymywanie w tajemnicy ich spraw oraz okazywanie im szacunku nawet gdy trudno akceptować ich zachowania. Tworzą także fuzje ze strategiami układania planu działania przy rozwiązywaniu problemu, robienia tego wszystkiego, by go rozwikłać, by nie rozpraszały i nie przeszkadzały w tym inne myśli i działania, odkładania ich na później, po to, by krok po kroku robić 
to, co jest do zrobienia, uczyć się tego doświadczać oraz zwracania się ku religii, znalezienia w niej ukojenia, zawierzenia Bogu. Gdy tymczasem buforem jest globalna gotowość do asertywności i strategia zaprzeczania, wmawiania sobie, że „to nie dzieje się naprawdę", i nie przyjmowania do wiadomości, że to się stało, udawania i zachowywania się tak, jakby się nie stało.

Analiza zaś współczynników determinacji Umiejętności planowania upoważnia do stwierdzenia, że zmienna ta wyjaśniana jest za pomocą zmiennych niezależnych uwzględnionych w modelu funkcji regresji na poziomie 38\%. Stwierdzono tutaj istotność statystyczną lub zbliżoną do niej siedmiu cząstkowych współczynników regresji, w tym jedynie dwa o charakterze wprost proporcjonalnym, wskazując tym samym, że badani studenci analizowane umiejętności: radzenia sobie ze swoimi obawami i lękami, znajdowania przyczyn problemu, wyznaczania celów, określania swoich możliwości, zbierania informacji, szeregowania problemów według ważności, podejmowania decyzji czy koncentrowania się na zadaniu, łączą głównie ze strategią układania planu działania przy rozwiązywaniu problemu, robienia tego wszystkiego, by go rozwikłać, by nie rozpraszały i nie przeszkadzały w tym inne myśli i działania, odkładania ich na później, po to, by krok po kroku robić to, co jest do zrobienia, uczyć się tego doświadczać oraz ze stopniem świadomej, subiektywnej postawy wobec siebie, wobec innych, emocji związanych z własną osobą, powiązanej z poznawczymi sądami o sobie. W opozycji do nich stoją umiejętności przyjmowania pochwał i krytyki w sytuacjach, w których spotyka się zarówno ze słuszną, jak i z niesłuszną oceną ze strony innych ludzi oraz otwartego wyrażania uczuć w sytuacji odczuwania zadowolenia, dumy czy radości i takiego samego, czyli szczerego wyrażania uczuć w sytuacji odczuwania niezadowolenia, irytacji i złości, a także otwartego i szczerego mówienia o podzielaniu cudzych opinii, czy otwartego przyznawanie się do swoich upodobań, pomimo braku zewnętrznej aprobaty dla nich, a ponadto ze strategiami spożywania alkoholu lub przyjmowania innych środków odurzających oraz zaprzeczania, czyli mówienia sobie, że „to nie dzieje się naprawdę", nie przyjmowania do wiadomości, że to się stało, udawania i zachowywania się tak, jakby się nie stało.

\section{ZAKOŃCZENIE}

Zastosowanie analizy regresyjnej krokowej przyczyniło się do otrzymania specyficznych struktur związków między umiejętnościami prospołecznymi studentów kierunków nauczycielskich a ich podmiotowymi wymiarami psychospołecznego funkcjonowania, takimi jak: gotowość do asertywności, strategie radzenia sobie w sytuacjach trudnych i samoocena. Każda $\mathrm{z}$ nich, w tym przypadku model re- 
gresyjny, na tyle precyzyjnie charakteryzuje uzyskane związki, na ile mogą one pretendować do miana autonomicznych wniosków, a mogą, ponieważ mają solidne oparcie w empirii. Pozwala ona bowiem ustalić procent wariancji zmiennej zależnej wyjaśnianej przez liniową kombinację zmiennych niezależnych, czyli określić, jaki układ wielu zmiennych niezależnych ma znaczenie w wyjaśnianiu jednej zmiennej zależnej. Pamiętając jednocześnie, że współczynniki regresji wielokrotnej mają różne jednostki miary, dlatego też nie można ich użyć do bezpośredniego porównania siły powiązania poszczególnych zmiennych niezależnych ze zmienną zależną, ale w przypadku niniejszych analiz nie było takiej potrzeby. Przy zastosowaniu zatem tej metody statystycznej margines nadinterpretacji jest bardzo ograniczony, co nie oznacza jednak, że ma charakter zamknięty. Nie wszystkie bowiem $z$ otrzymanych struktur są ostatecznym rozstrzygnięciem, ponieważ niektóre $\mathrm{z}$ nich należy traktować jedynie jako propozycje dalszych analiz, tym bardziej, gdy dotyczą weryfikacji szczegółowych hipotez w odniesieniu tak do zmiennej zależnej umiejętności prospołecznych, jak i poszczególnych zmiennych niezależnych, rozpatrywanych wyłącznie w kontekście całej grupy badanych studentów, bez uwzględnienia chociażby wielu zmiennych pośredniczących o charakterze moderującym. Wówczas należałoby dodatkowo odwołać się do efektu porównawczego. Brakuje również istotnej informacji o kierunku oddziaływania na siebie analizowanych zmiennych, do czego konieczne są kolejne działania eksploracyjne, poprzez na przykład utworzenie modeli ścieżkowych. Również struktury, tutaj modele otrzymanych związków, nie są znacząco zróżnicowane jakościowo, co wynika $\mathrm{z}$ ich reprezentacji, czyli z konkretnych rozkładów danych. Z uwagi jednak na otrzymane wartości modalne w porównywanych wskaźnikach są na tyle wyraziste, na ile było to możliwe w wymiarze przeprowadzenia analiz ilościowych. Cząstkowe wyniki są niewątpliwie w wielu obszarach analiz zbieżne $\mathrm{z}$ dotychczasowymi danymi w odniesieniu do różnych grup nauczycieli (zob. Zubrzycka-Maciąg 2013; Zubrzycka-Maciąg, Kirenko 2015) i studentów kierunków nauczycielskich (zob. Kirenko 2019), a przez to weryfikują przypuszczenie o ich złożonym charakterze.

\section{LITERATURA}

Byra S., 2012, Przystosowanie do życia z niepetnosprawnościa ruchową i choroba przewlekła. Struktura i uwarunkowania. Lublin, Wydawnictwo UMCS.

Dylak S., 1995, Wizualizacja w kształceniu nauczycieli. Poznań, Wydawnictwo Naukowe UAM.

Dzwonkowska I., Lachowicz-Tabaczek K., Łaguna M., 2008, Samoocena i jej pomiar. Polska adaptacja skali SES M. Rosenberga. Podręcznik. Warszawa, Pracownia Tes- 
tów Psychologicznych. Goldstein A.P., Glick B., Gibbs J.C., 2008, ART. Program zastępowania agresji. Warszawa, Instytut Amity.

Kacprzak L., 2006, Pedeutologiczne rozważania o nauczycielu. Piła, Państwowa Wyższa Szkoła Zawodowa im. St. Staszica.

Karolczak-Biernacka B., 1996, Kondycja nauczyciela. „Edukacja i Dialog”, 1, 21-28.

Kirenko J., 1991, Psychospołeczne przystosowanie osób z paraplegią. Lublin, Wydawnictwo UMCS.

Kirenko J., 2019, Perspektywa przypadkowych zdarzeń a umiejętności społeczne studentów kierunków nauczycielskich z różnym poziomem samooceny. „Edukacja Technika - Informatyka. Kwartalnik Naukowy", 1/27 (w druku).

Kirenko J., Zubrzycka-Maciąg T., 2011, Współczesny nauczyciel. Studium wypalenia zawodowego. Lublin, Wydawnictwo UMCS.

Lazarus R.S., Folkman S., 1984, Stress, Appraisal and Coping. New York, Springer Publishing Company.

Poprawa R., 2001, Asertywność wobec aktywności zawodowej człowieka. W: B. Wojtasik (red.), Podejmowanie decyzji zawodowych przez młodzież i osoby dorosłe w nowej rzeczywistości społeczno-politycznej. Wrocław, Wydawnictwo Instytutu Technologii Eksploatacji, 109-123.

Wrześniewski K., 1996, Stres a strategie radzenia sobie ze stresem. Problemy pomiaru. W: I. Heszen-Niejodek, Z. Ratajczak (red.), Człowiek w sytuacji stresu. Problemy teoretyczne i metodologiczne. Katowice, Wydawnictwo Uniwersytetu Śląskiego.

Zubrzycka-Maciąg T., 2013, Psychospołeczne uwarunkowania stresu nauczycielek szkót podstawowych i gimnazjów. Lublin, Wydawnictwo UMCS.

Zubrzycka-Maciąg T., Kirenko J., 2015, Asertywność nauczycieli. Badania empiryczne. Lublin, Wydawnictwo UMCS.

\title{
ENTITIES OF THE CORRELATIVE SKILLS OF PROSPECTIVE TEACHERS DEGREE STUDENTS
}

\begin{abstract}
Solving the main research problem included in the question about the relationship between variables, dependent - prosocial skills, and independent, called subjective, in the dimensions of: assertiveness, coping in difficult situations and self-assessment, was tested using: Social Skills Questionnaire (KUS - AP Goldstein), Questionnaire of Assertiveness of the Teacher-Educator (KAN / W - T. Zubrzycka-Maciąg, J. Kirenko), COPE Questionnaire (COPE - CS Carver, MS Scheier, JK Weintraub) and the Self-Assessment Scale (SES - M. Rosenberg), 244 students of the faculties teachers, including 222 women (90.98\%) and 22 men $(9.02 \%)$. The age of the respondents ranged from 21 to 46 years, with an average of 25.29 years. They were students of pedagogy, English philology and pre-school and early school education
\end{abstract}


from three universities in the Lublin region. A specific structure of compounds of selected variables was obtained, those that have a significant support in empiricum were highlighted. The applied multiple regression enabled the adoption of relatively precise characteristics of the compounds obtained, aspiring to be called autonomous applications.

Keywords: students of teaching faculties, prosocial skills assertiveness, coping with difficult situations, self-esteem 